\title{
Epimeria schiaparelli sp. nov., an amphipod crustacean (family Epimeriidae) from the Ross Sea, Antarctica, with molecular characterisation of the species complex
}

\author{
ANNE-NINA LÖRZ ${ }^{1}$ ELIZABETH W. MAAS ${ }^{1}$, KATRIN LINSE $^{2} \&$ GRAHAM D. FENWICK $^{3}$ \\ ${ }^{1}$ National Institute of Water \& Atmospheric Research, Private Bag 14901, Kilbirnie Wellington, New Zealand; corresponding author. \\ ${ }^{2}$ British Antarctic Survey, Natural Environmental Research Council, High Cross, Madingley Road, Cambridge, CB3 OET, UK \\ ${ }^{3}$ National Institute of Water \& Atmospheric Research, P.O. Box 8602, Christchurch, New Zealand.
}

\begin{abstract}
Epimeria schiaparelli sp. nov. from the Ross Sea, Antarctica, is described in detail. The new species occurs on the shelf in 130-350 m depth. Epimeria schiaparelli can be distinguished from the most similar species, E. similis Chevreux, 1912 and E. macrodonta Walker, 1906 by a relatively short rostrum and a short second pereonite amongst other characters. Two distinct colour patterns are reported. Partial gene sequences of the mitochondrial cytochrome oxidase subunit I (COI) from 11 specimens of $E$. schiaparelli confirm that this species is new to science and closely related to $E$. similis, $E$. macrodonta and E. reoproi. The recent and historical separation of this Antarctic species is discussed. The syntypes of $E$. macrodonta consist of two species, so a lectotype is here designated.
\end{abstract}

Key words: Antarctica, taxonomy, Amphipoda, Crustacea, Epimeriidae, Epimeria, Cytochrome oxidase I.

\section{Introduction}

Species of the amphipod family Epimeriidae dominate the Antarctic shelf benthos (Coleman \& Barnard 1991; Lörz 2003). Currently 24 species in five genera of Epimeriidae are known from the Southern Ocean, 21 of these belonging to the genus Epimeria. During the joint New Zealand-Italian BioRoss Expedition TAN0402 to the western Ross Sea and the Balleny Islands in early 2004, more than 3000 amphipods were collected from 20-1200 m depths. Lysianassidae was the most speciose amphipod family, followed by the Epimeriidae and Eusiridae. The Ischyroceridae was most abundant numerically, comprising nearly one-third of all specimens collected (868 specimens), followed by the Lysianassidae (528) and Epimeriidae (291).

Among the epimeriid amphipods obtained were several specimens belonging to the diverse Antarctic genus Epimeria Costa, 1851. Preliminary examination revealed at least eight species, one of which proved new to science and is here described.

\section{Material and methods}

Four different gear types were used to collect benthic invertebrates from RV Tangaroa during the expedition: Van Veen grabs, Agassiz trawls, an epibenthic sled and a rock dredge. Amphipods were sorted from collections immediately (often alive), fixed in $98 \%$ ethanol and transferred to $70 \%$ ethanol about four months later. Specimens were examined and dissected using a Leica MZ9.5 stereomicroscope and drawn using a camera 
lucida attachment. Small appendages (mouthparts, uropods, telson) were temporarily mounted in lactic acid, stained with lignin pink and examined and drawn using a Nikon compound microscope fitted with a camera lucida. The body lengths of specimens examined were measured by tracing individual's mid-trunk lengths (tip of the rostrum to end of telson) using a camera lucida, measuring this curved length and then converting this to actual animal body length by correcting for magnification. All illustrations were inked electronically using a Wacom Board.

Setal terminology follows Watling (1989). Within the description, abbreviations are used for slender setae (SS) and robust setae (RS). We use the terms cusp and spine to refer to non-articulating processes or extensions of the cuticle.

Type material is held in the National Institute of Water and Atmospheric Research Invertebrate Collection at Wellington (NIWA), New Zealand. Additional paratypes were deposited at the Museum für Naturkunde (ZMB), Berlin, Germany, and the National Museum of New Zealand Te Papa Tongarewa (NMNZ), Wellington, New Zealand.

Genomic DNA was isolated from amphipod pereopods using the DNEasy tissue extraction kit (Qiagen Ltd) and quantified using the PicoGreen quantification kit (Molecular Probes, Invitrogen Ltd). The partial mitochondrial cytochrome oxidase subunit I (COI) gene was amplified using the universals primers described by Folmer et al. 1994 using Eppendorf HotMaster ${ }^{\circledast}$ Mix (Eppendorf, Germany), $0.2 \mu \mathrm{M}$ of each primer and between 20-200 ng of genomic DNA. PCR reactions were carried out in a GeneAmp 2720 thermocycler (Applied Biosystems, Foster City, California, USA) using the following conditions: an initial hold at $95^{\circ} \mathrm{C}$ for 5 minutes and then 30 cycles of $95^{\circ} \mathrm{C}$ for 30 seconds; $50^{\circ} \mathrm{C}$ for 30 seconds; $72^{\circ} \mathrm{C}$ for 1.5 minutes; and a final extension at $72^{\circ} \mathrm{C}$ for 7 minutes. PCR products were purified using QIAquick Spin Columns (Qiagen Ltd) and quantified using the PicoGreen Kit (Molecular Probes, Invitrogen Ltd). Sequencing of the COI gene was carried out by the Allan Wilson Centre Genome Service, Massey University, Palmerston North, New Zealand, using the amplification primers.

The proof-read sequences of the 11 specimens were aligned using ARB software (Ludwig et al. 2004) against reference sequences of other Epimeria species (E. georgiana, E. macrodonta, E. reoproi, E. robusta, E. rubrieques, E. similis) and Eusirus cf. perdentatus Chevreux, 1912 obtained from European Molecular Biology Laboratory (EMBL) genome sequence database. Eusirus cf. perdentatus was chosen as the outgroup, as it had previously been used by Lörz \& Held (2004) for this purposes for the analysis of species within the Epimeriidae family and had proven to be useful. Evolutionary distances were calculated from sequence pair dissimilarities using only unambiguously sequenced positions, and phylograms were generated using PAUP*4.0b10 (Swofford 2002) under the heuristic search (parameters used: random addition sequence, TBR 100 replicates). To assess relative support for clades, 1000 bootstrap replicates were calculated in PAUP*. The partial COI gene sequences determined in this study are deposited in the EMBL database and the accession number for each specimen is shown in Table 2.

\section{Systematics \\ Order AMPHIPODA Latreille, 1816 \\ Suborder GAMMARIDEA Latreille, 1802 \\ Family EPIMERIIDAE Boeck, 1871}

\section{Genus Epimeria Costa, 1851}

The most recent family diagnosis for the Epimeriidae is that of Coleman and Barnard (1991), and Barnard and Karaman (1991), respectively. The first volume of Synopsis of benthic Amphipoda of the Southern Ocean by Charles Oliver Coleman, including a key to the Antarctic species of Epimeriidae, will be published shortly. 
Epimeria schiaparelli sp. nov. (Figs 1-7)

Material examined (all western Ross Sea, Antarctica)

Holotype: ovig. ? (29.9 mm,), NIWA 18174, TAN0402/195, epibenthic sled, 71 37.32-37.14' S, $170^{\circ}$ 55.38-55.54' E, 28 February 2004, $244 \mathrm{~m}$.

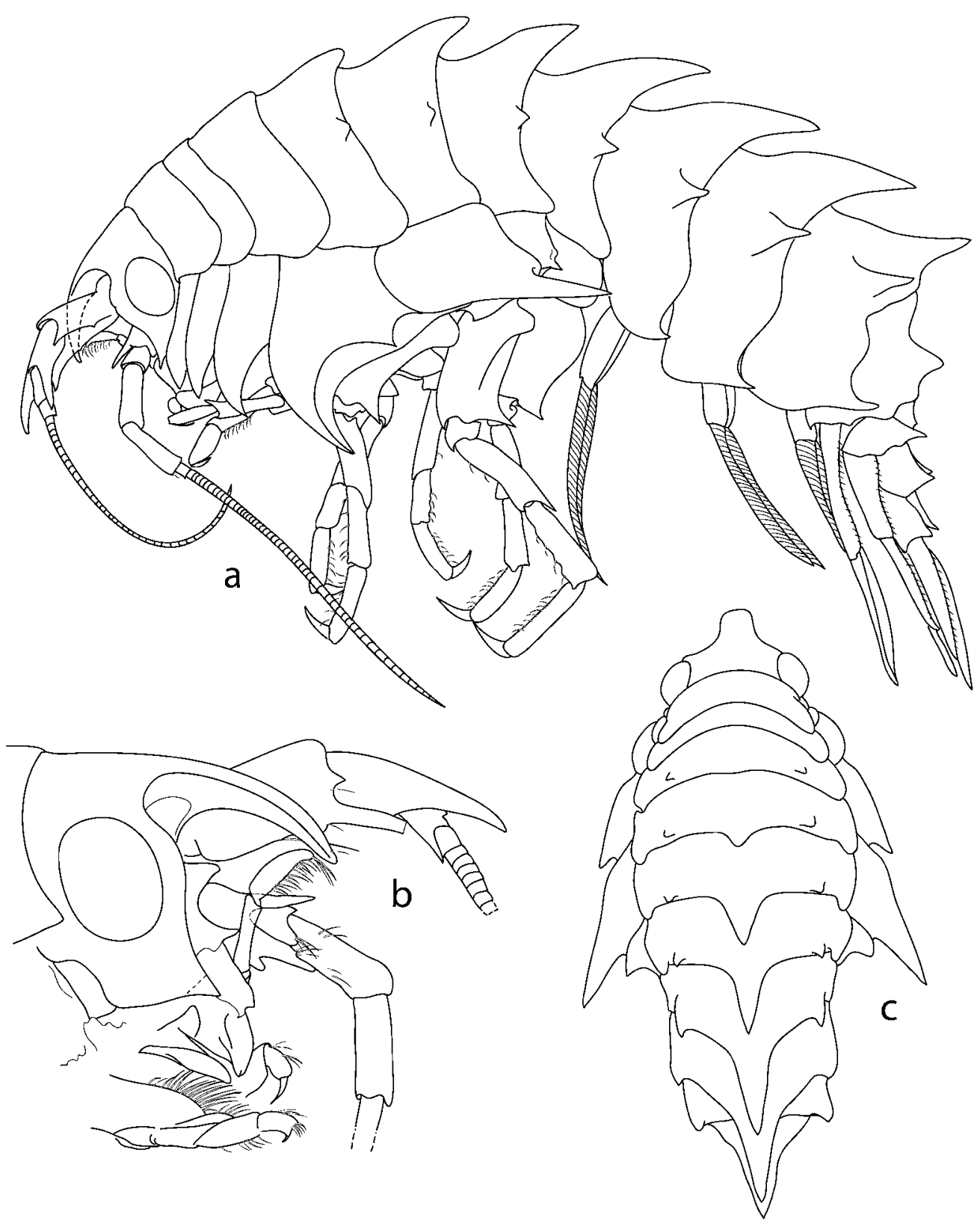

FIGURE 1. Epimeria schiaparelli sp. nov. Holotype, 29.9 mm, NIWA 18174. A, lateral habitus; B, head; C, dorsal habitus.

Paratypes: Each registration number refers to a single specimen unless otherwise stated; NIWA 18175, adult ?, $21.6 \mathrm{~mm}$, NIWA 18187, seven specimens, TAN0402/195, epibenthic sled, 71 ${ }^{\circ} 37.32-37.14$ 'S, $170^{\circ}$ 55.38-55.54E, 28 February 2004, 244 m; NIWA 18181, NIWA 18183, NIWA 18193, NIWA 18198, TAN0402/22, epibenthic sled, $71^{\circ} 48.06^{\prime}-47.91^{\prime} \mathrm{S}, 170^{\circ}$ 56.48'-57.56'E, 09 February 2004, $151 \mathrm{~m}$; NIWA 18184, TAN0402/25, epibenthic sled, $71^{\circ} 47.92-47.78$ 'S, $170^{\circ} 55.97-56.95^{\prime} \mathrm{E}, 09$ February $2004,127 \mathrm{~m}$; NIWA 18202, TAN0402/33, epibenthic sled, 71 ${ }^{\circ} 45.28-45.35 ' \mathrm{~S}, 171^{\circ} 25.02-23.94 ' \mathrm{E}, 10$ February 2004,282 m; NIWA 18176, ovigerous, NIWA 18178, NIWA 18190, NIWA 18191, ZMB 27576-78, TAN0402/39, 
epibenthic sled, 71 ${ }^{\circ} 45.30-45.53 ' \mathrm{~S}, 171^{\circ} 8.55-9.16^{\prime} \mathrm{E}, 10$ February 2004, $251 \mathrm{~m}$; NIWA 18180, ZMB 2757678 (former NIWA 18196), TAN0402/112, epibenthic sled, $71^{\circ} 17.61-17.77 ' \mathrm{~S}, 170^{\circ} 34.60-35.45^{\prime} \mathrm{E}, 18$ February 2004, 346 m; NIWA 18194, TAN0402/116, epibenthic sled, 71 ${ }^{\circ} 17.93-18.21$ 'S, 170 $32.43-33.02^{\circ} \mathrm{E}, 18$ February 2004, $312 \mathrm{~m}$; NIWA 18182, TAN0402/33, epibenthic sled, 71 ${ }^{\circ} 45.28-45.35 ' \mathrm{~S}, 171^{\circ} 25.02-23.94 ' \mathrm{E}$, 10 February 2004, 282 m; NIWA 18188, TAN0402/189, van Veen Grab, 71³4.49'S, 17052.24'E, 27 February 2004, 231 m; NIWA 18177, NIWA 18195, NIWA 18197, NIWA 18199, TAN0402/140, epibenthic sled, 72 $2^{\circ}$ 0.81-1.08'S, 170 46.47-45.97' E, 26 February 2004, $231 \mathrm{~m}$; NIWA 18192, TAN0402/190, Epibenthic Sled, 71 34.75-34.97'S, 170 52.37-52.43'E, 27 February 2004, 230 m; NIWA 18187, NMNZ Cr. 10024 (former NIWA 18201, 3 specimens), TAN0402/195, epibenthic sled, 71 ${ }^{\circ} 37.32-37.14{ }^{\prime} \mathrm{S}, 170^{\circ} 55.38-55.54^{\prime} \mathrm{E}$, 28 February 2004, 244 m; NIWA 18179, TAN0402/197, epibenthic sled, 71 $37.24-37.11^{\circ} \mathrm{S}, 170^{\circ} 51.99$ 52.73'E, 28 February 2004, 198 m; NIWA 18185, TAN0402/198, Van Veen grab, 71³7.04'S, 170 $53.61^{\circ} \mathrm{E}, 28$ February 2004, $222 \mathrm{~m}$.

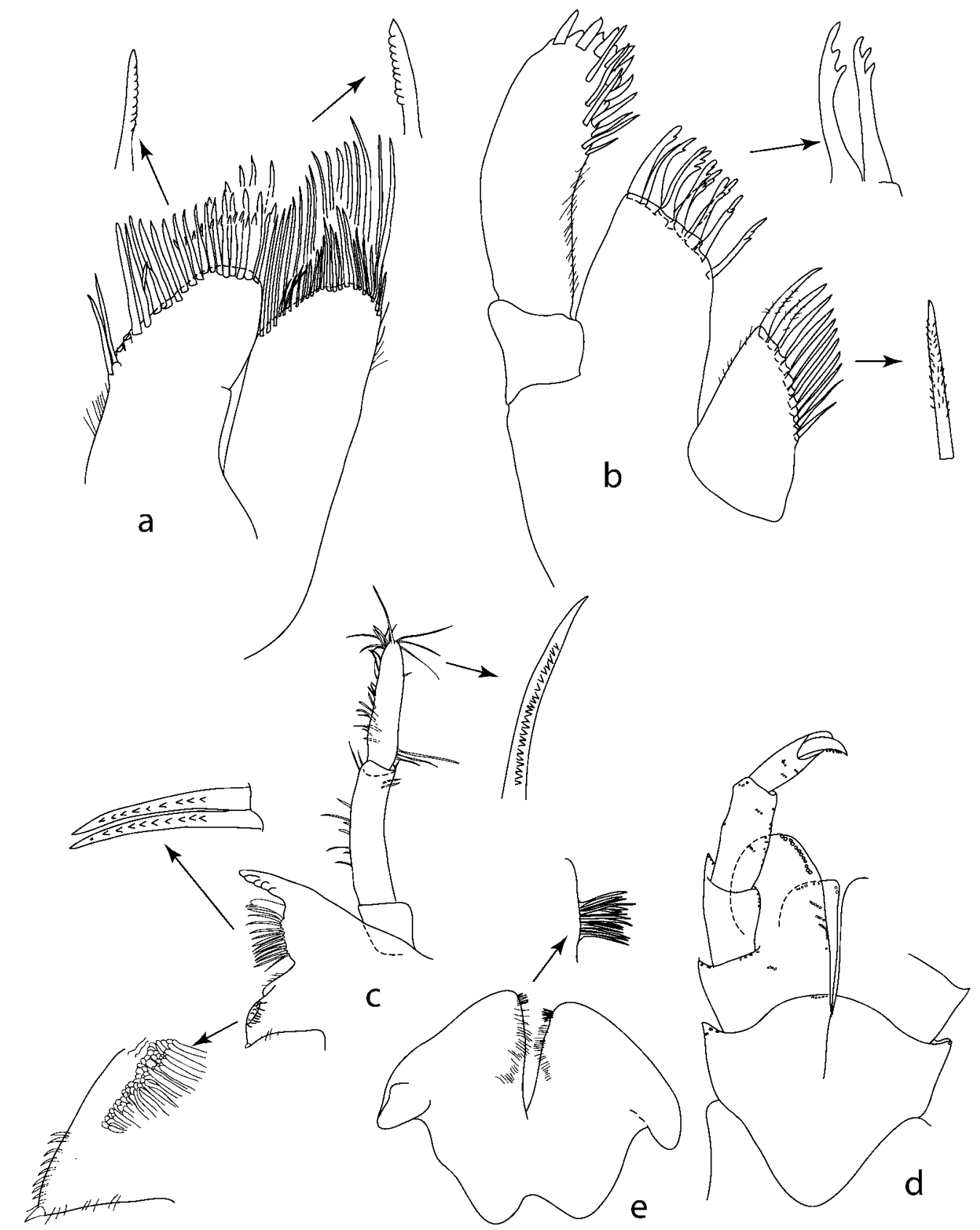

FIGURE 2. Epimeria schiaparelli sp. nov. Holotype, 29.9 mm, NIWA 18174. A, maxilla 2; B, maxilla 1; C, mandible; D, maxilliped; E, lower lip. 


\section{Etymology}

The species is dedicated to Dr Stefano Schiaparelli, who kindly shared his enthusiasm and knowledge on board during the BioRoss Antarctic expedition.

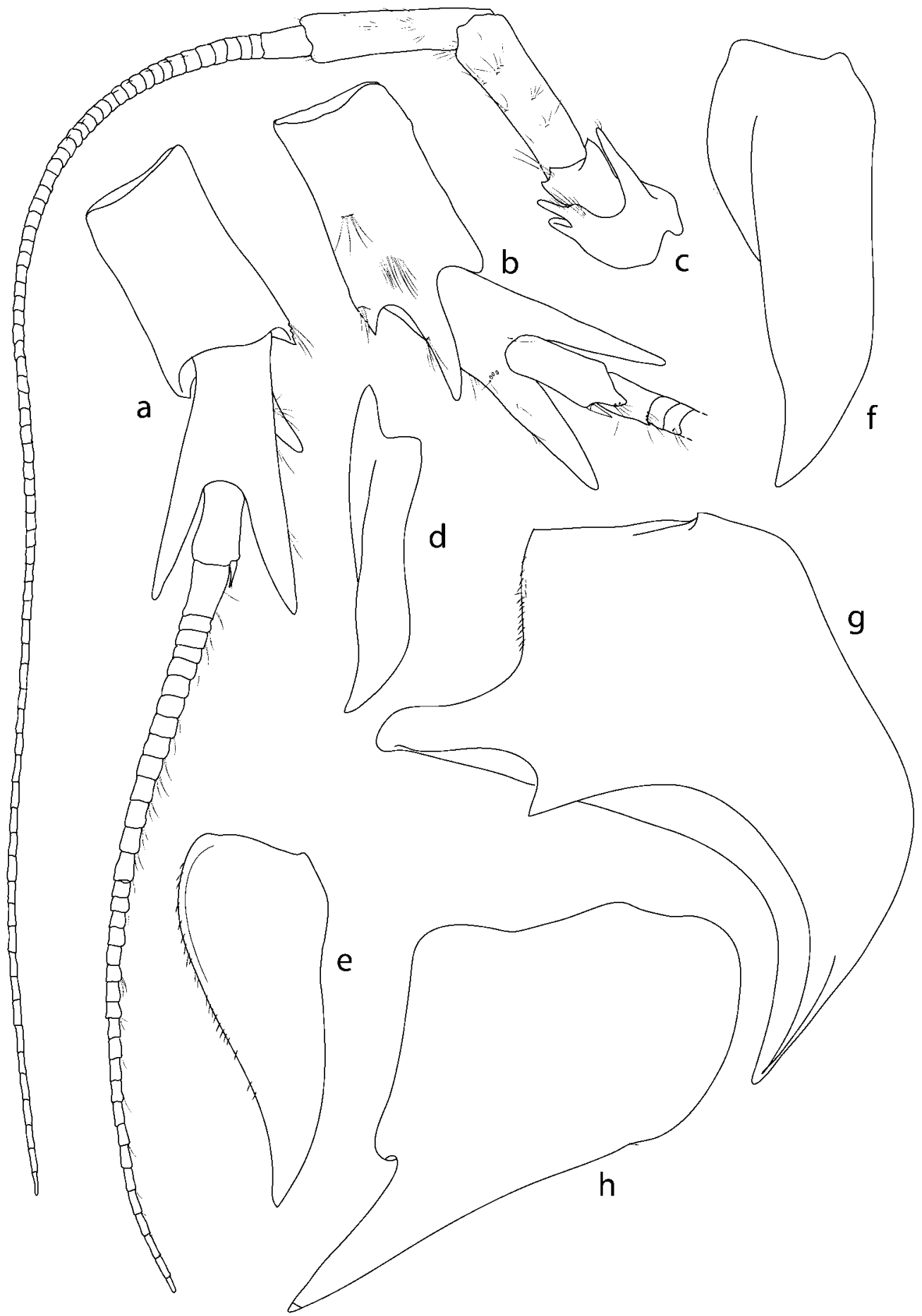

FIGURE 3. Epimeria schiaparelli sp. nov. Holotype, 29.9 mm, NIWA 18174. A, antenna 1; B, antenna 1 peduncle; C, antenna $2 ; \mathrm{D}$, coxa $1 ; \mathrm{E}$, coxa $2 ; \mathrm{F}$, coxa $3 ; \mathrm{G}$, coxa $4 ; \mathrm{H}$, coxa 5.

\section{Description}

Head higher than long, anterior cephalic margin sinuous, lateral cephalic lobe acutely produced; rostrum (Fig. 1A, B) c. $1.5 \mathrm{x}$ head length, reaching proximal part of antenna 1 peduncle article 2; eye oval, $0.5 \mathrm{x}$ head height, set back from anterior cephalic lobe margin. Pereonite 1 subequal in length to head (excluding ros- 
trum), pereonite 2 c. $0.5 \mathrm{x}$ length of 1 , pereonites 1 and 2 lacking mid-dorsal or dorsolateral processes; pereonite $3 c .1 .3 \mathrm{x}$ longer than 1 , posterior margin with weak tooth appearing as thickening in lateral aspect, with weak dorsolateral process; pereonite 4 with blunt mid-dorsal process overhanging pereonite 5 , blunt dorsolateral carina weakly developed; pereonites 5-7 and pleonites 1-3 with large, acute mid-dorsal teeth curved posteriorly to overhang following somite and distinct, dorsolateral processes, obtuse on 5-6, acute on 7 and pleonites 1-3. Epimeron 1 (Fig. 6A) narrow, anteroventral angle rounded, with acute posterodistal tooth, posterior margin concave distally; epimera 2-3 similar to 1, transverse ventral margins increasingly longer, posterior excavations shallower, posterodistal cusps increasingly produced. Urosomite 1 (Fig. 1A) with acute cone mid-dorsally, lacking dorsolateral processes; urosomite 2 shortest; urosomites 2 and 3 lacking mid-dorsal processes, with acute dorsolateral carinae at posterior margin.

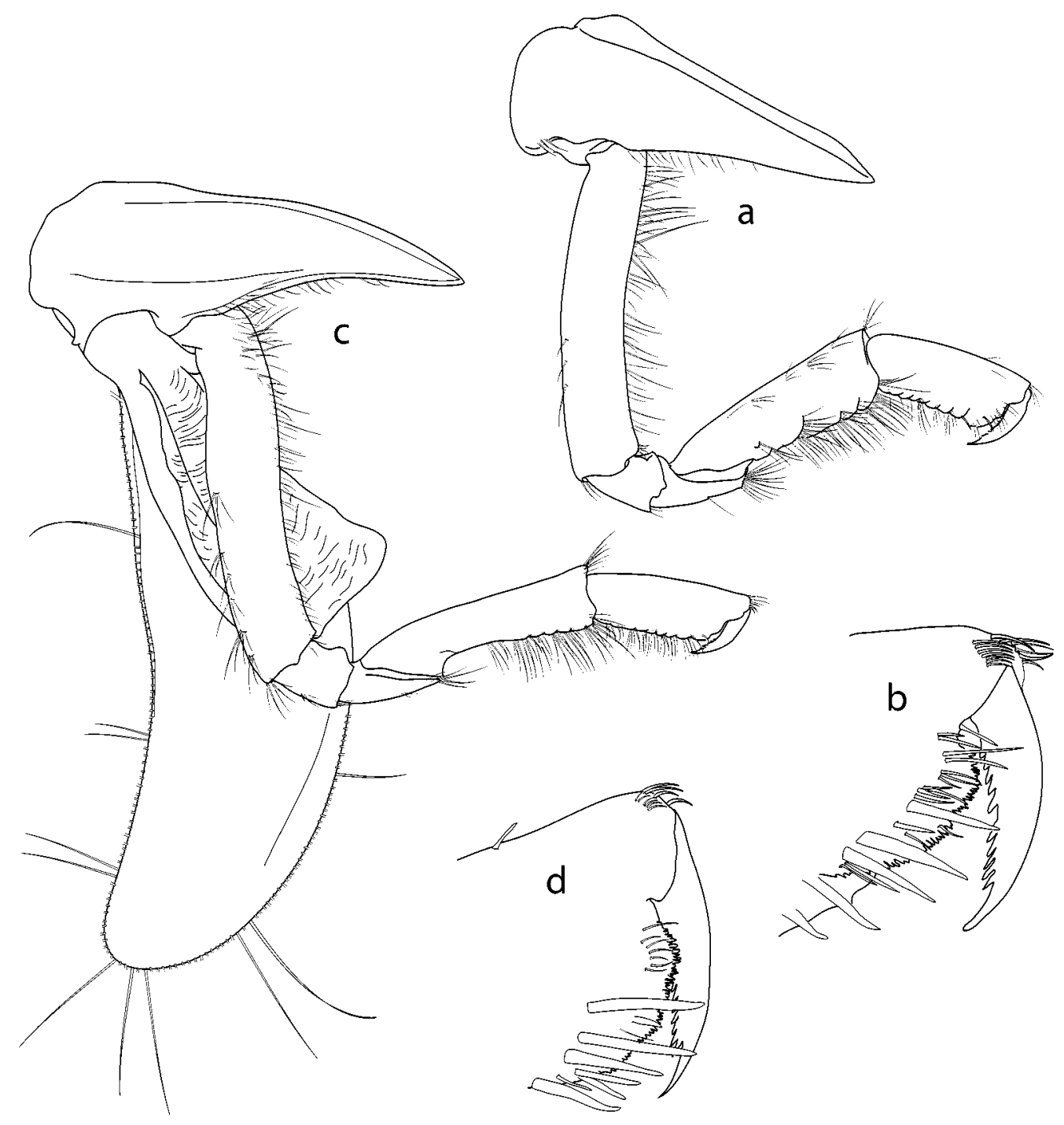

FIGURE 4. Epimeria schiaparelli sp. nov. Holotype, 29.9 mm, NIWA 18174. A, gnathopod 1; B, detail of gnathopod 1; C, gnathopod 2; D, detail of gnathopod 2.

Antenna 1 (Fig. 3A, B): peduncle article 1 with many plumose setae distal margin with 2 short and 1 long processes; article 2 with 2 long acute processes distally, length (including processes) slightly shorter than article 1; article 3 shortest; accessory flagellum scale-like; primary flagellum of 35 articles. Antenna 2 (Fig. 3C) (longer than A1; article 2 with 2 large acute distal cusps; peduncle article 3 with short obtuse distal cusps; articles 4 and 5 lacking distal processes, lengths subequal; flagellum with 75 articles. 
Mandible (Fig. 2C): incisor and lacinia mobilis strongly dentate; molar produced and triturative; palp article 3 densely setose medially, with long stout SS distally. Lower lip (Fig. 2E) (hypopharynx) with wide lobes and groups of setae on distomedial angles, hypopharyngeal gap narrow. Maxilla 1 (Fig. 2B) medial plate subtriangular, obliquely convex inner margin with 11 stout, plumose SS; lateral plate distal margin oblique, with 11 medially lobate RS; palp strongly exceeding outer plate; palp article 1 short, article 2 slightly curved medially with stout SS distomedially, stout RS distally. Maxilla 2 (Fig. 2A) with long, distally crenulate setae distally on lateral and medial plates. Maxilliped (Fig. 2D) lateral plate broadly rounded distally, reaching midpoint of carpus, medial plate with nodular RS and a row of long plumose SS on medial, anterior face; palp medial margin strongly setose; merus distally expanded; dactyl with serrate medial margin.

Gnathopod 1 (Fig. 4A, B): coxa 1 long and slender, anterior margin straight, broadly rounded anterodistally to form acute posterodistal corner, posterior margin straight; basis linear, slender, both margins with numerous fine SS; merus slightly longer than ischium, anterior margin very short, distal margin oblique, posterodistal angle acute, setose; carpus slightly expanded distally, distal margin transverse, anterodistal angle with SS, distal half of posterior margin with long SS; propodus subrectangular, $0.6 \mathrm{x}$ carpus length, anterior margin naked except for distal fringe of short SS, palm finely crenulate, slightly oblique, with cluster of RS defining rounded distal margin, posterior margin with numerous long SS; dactylus slender, slightly curved, posterior margin strongly serrate. Gnathopod 2 (Fig. 4C, D) slightly longer than gnathopod 1; coxa 2 similar in shape to coxa 1 , tapering distally, posterior margin slightly concave; basis linear, extending $50 \%$ below coxa; merus short, $1.3 \mathrm{x}$ ischium length, anterior margin very short, distal margin obliquely articulating with carpus, with group of 4 or 5 SS posterodistally; carpus curved proximally, widened distally to $0.3 \mathrm{x}$ length, 4.5 $\mathrm{x}$ merus length, anterior margin naked except for transverse row of SS distally, posterior margin with numerous stout SS distally; propodus $0.6 \mathrm{x}$ carpus length, $0.5 \mathrm{x}$ as wide as long, palm almost transverse, rounded, finely crenulated, lined with numerous submarginal RS; dactylus large, slightly exceeding palm, posterior margin serrate. Pereopod 3 (Fig. 5A): coxa wider and slightly longer than coxa 2, posterior margin strongly concave; basis linear, extending just further than coxa, anterior margin finely setulose, posterior margin with 7 groups of SS; merus slightly expanded distally, anterodistal angle weakly produced into narrow flange overhanging distal c. 0.2 of carpus; carpus $c .0 .5 \mathrm{x}$ merus length, slightly widened distally, anterior margin naked, posterior margin with 6 pairs of RS; propodus $1.3 \mathrm{x}$ carpus length, naked anteriorly, posterior margin with 810 pairs of RS; dactylus stout, curved, $0.5 \times$ propodus length. Pereopod 4 (Fig. 5B): coxa slightly longer than $3,1.5 \mathrm{x}$ longer than wide, anterior margin strongly convex, produced into stout, acute posterodistal cusp directed posterodistally, posterior margin divided at mid point by subacute cusp into two concave sections; basis to dactylus as for pereopod 3. Pereopod 5 (Fig. 5D): coxa subrectangular, wider than long, posterodistal corner produced as slender cusp c. $0.5 \mathrm{x}$ length of rest of coxa; posterior margin weakly concave; basis scarcely covered by coxa, expanded into irregular posterior flange with proximal rounded lobe and acute triangular posterodistal tooth; merus constricted proximally, posterodistally produced to overhang c. 0.2 carpus; carpus slightly widened distally, $0.8 \mathrm{x}$ merus length; propodus sublinear, subequal in length to merus, posterior margin with 8 pairs of RS; dactylus curved, stout, c. 0.5 x propodus length. Pereopod 6 (Fig. 5E): coxa anterior half hidden by coxa 5 , anterior margin weakly concave, posterodistal corner produced into short, posterolateral tooth, posterior margin broadly rounded; basis to dactylus as in pereopod 5. Pereopod 7 (Fig. 5C): coxa subrectangular, $1.1 \mathrm{x}$ wider than long, slightly narrower distally; basis expanded posteriorly, margin sinuous, broadly rounded proximally, distal concavity forming acute cusp at posterodistal angle; ischium to dactylus as in pereopods 5 and 6. 


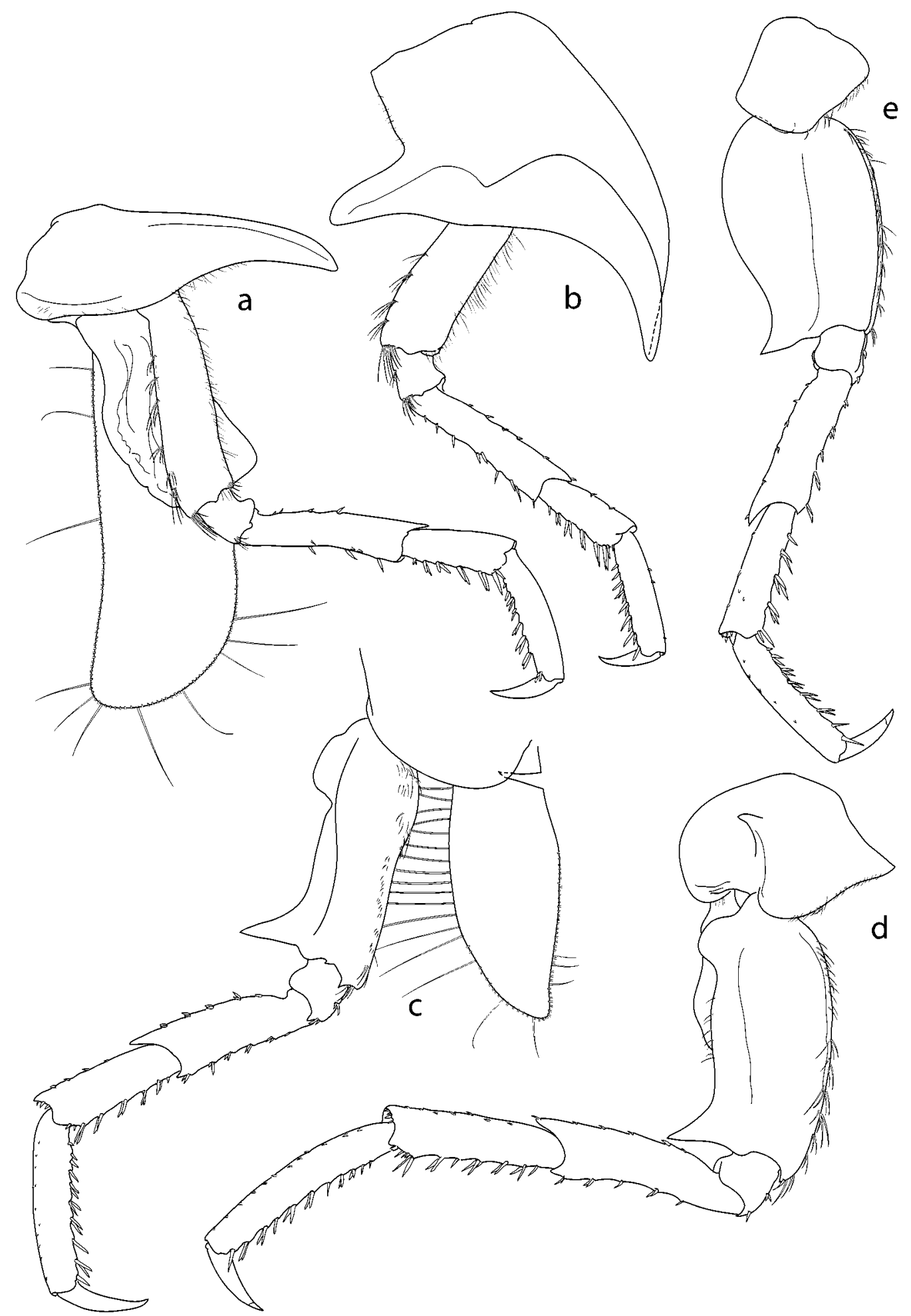

FIGURE 5. Epimeria schiaparelli sp. nov. Holotype, 29.9 mm, NIWA 18174. A, pereopod 3; B, pereopod 4; C, pereopod 7; D, pereopod 5; E, pereopod 6.

Uropods extending equally, rami apices naked. Uropod 1 (Fig. 6C): peduncle subequal in length to inner ramus, medial margin with few RS proximally and 1 distally, distal 0.6 of lateral margin with close row of short RS; inner ramus lateral margin with spaced row of short RS, medial margin with sparse RS; outer ramus marginally shorter than inner, marginal setation as in inner ramus. Uropod 2 (Fig. 6D): peduncle naked except for 1 or 2 short RS distally on each margin; inner ramus length 1.3 x outer ramus, medial margin with sparse 
RS, distal lateral margin with close RS; outer ramus 1.2 x peduncle length, both margins with close rows of short RS over mid 0.5 of length. Uropod 3 (Fig. 6E): peduncle short, c. $0.5 \mathrm{x}$ length of inner ramus, produced into acute process extending c. 0.15 alongside inner ramus; outer ramus over 0.6 of its length, medial margin with sparse row of short RS along full length, inner margin with sparse short RS along distal 0.5 of length; outer ramus $0.8 \mathrm{x}$ length of inner, almost twice as long as peduncle, lateral margin with dense row of RS over proximal 0.6 of length, medial margin with RS confined to distal 0.3 of length. Telson (Fig. 6B) weakly tapering to c. 0.8 of basal width proximally, $1.2 \mathrm{x}$ longer than wide, v-shaped emargination $0.3 \mathrm{x}$ length, lobes triangular, subacute, narrowly rounded apically.

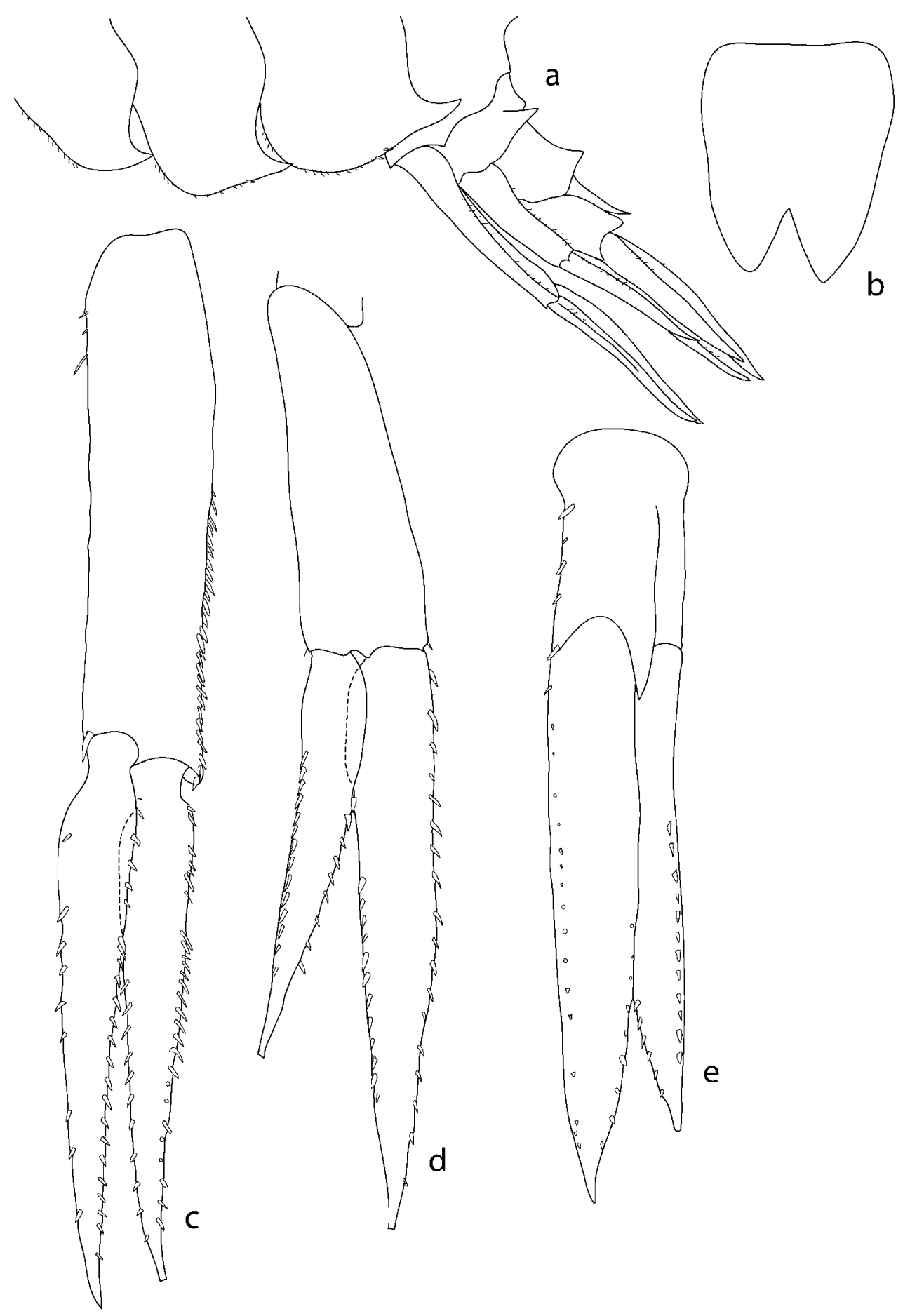

FIGURE 6. Epimeria schiaparelli sp. nov. Holotype, 29.9 mm, NIWA 18174. A, lateral view of epimeral plates, urosome; uropods 1-3, and telson; B, telson; C, uropod 1; D, uropod 2; E, uropod 3. 


\section{Remarks}

The new species, Epimeria schiaparelli sp. nov., superficially resembles Epimeria similis Chevreux, 1912 and E. macrodonta Walker, 1906 in the dorsal armature of pereonites 3-7 and pleonites 1-3. Epimeria schiaparelli, however, lacks carinae on pereonites 1 and 2, has a relatively short flexed rostrum and pereonite 2 is short relative to pereonite 1 . The main differences between species of this complex are summarized in Table 1 .

TABLE 1. Summary of morphological differences between Epimeria schiaparelli n. sp., Epimeria similis Chevreux, 1912 and E. macrodonta Walker, 1907.

\begin{tabular}{lccc}
\hline Characters & E. schiaparelli & E. similis & E. macrodonta \\
\hline Rostrum: head length & $1: 1$ & $1: 1$ & $2: 1$ \\
Antenna 1 article 2 lateral spine reaches article & Yes & No & Yes \\
3 & & & Thickened posterior margin \\
Pereonite 1 mid-dorsal process & None & $1: 2$ \\
Pereonite 2: 1 mid-dorsal length & $1: 2$ & Thickened posterior & None \\
Pereonite 2 mid-dorsal process & None & margin & None \\
& & Weak & Distinct carina \\
Pereonite 2 posterolateral process & None & Distinct carina & Distinct process \\
Pereonite 3 mid-dorsal process & Thickened posterior margin & Well developed & Long and narrow \\
Pereonite 3 dorsolateral process & Weak & Short and wide & $1.5: 1$ \\
Dorsal teeth (carinae) & Short and wide & $1: 1$ & $1: 1$ \\
Gnathopods 1-2, carpus: propodus, & $1.5: 1$ & $1.5: 1$ & $1: 3$ \\
Pereopods 3-4, basis: merus & $1: 1$ & $1: 3$ & Narrow \\
Uropod 3 peduncle: rami & $1: 4$ & Broader & Mid 7 \\
Coxae 1-3 & Broader & Mid 6 & Single, upright \\
Coxa 5 posterior spine extends to pereonite & $>$ Mid 7 & Bilobed, keel-like with & Concave \\
Pleonite 3 mid-dorsal carina & dorsal depression & Straight & Rounded, convex \\
Basis of pereonite 5 & Rounded & &
\end{tabular}

\section{Morphological variation}

The large dorsal pereonite and pleonite spines are so characteristic of species of Epimeria vary in size and shape in E. schiaparelli. The rostrum varies in relative length (mean rostrum: head ratio is 1:1.33 $(\mathrm{n}=18)$ ). In comparison, this ratio is greater in E. macrodonta (> 2:1) and up to at least 3:1, as in the newly designated lectotype.

The lateral spine on article 2 of antenna 1 always exceeds the length of the unproduced article (mean ratio spine: article is $5.9(\mathrm{n}=19))$ in E. schiaparelli. In E. macrodonta the lateral spine of article 2 of the first antenna is always longer than article 2. In E. similis, however, the lateral spine of antenna 1 article 2 is always shorter than the unproduced article.

Slight variation is present in development of the mid-dorsal and dorsolateral processes on pereonite 3 . In none of the specimens examined did the size of the pereonite 3 processes approach the equivalent processes on pereonite 4. A few specimens had slightly (c. 1.3 x) enlarged cusps on urosomites 2 and 3.

Similar variation is present in the development of the posteroproximal cusp on coxa 4 of E. schiaparelli. In some specimens, this cusp was represented by a small irregularity on the concave posterior margin. Usually, however, this cusp was strong and acute, with its length averaging $80 \%$ of the width of coxa $4(n=19)$.

\section{Molecular results}

Analysis of the data recovered 12 most parsimonious trees $(\mathrm{TL}=457, \mathrm{CI}=0.702, \mathrm{HI}=30298, \mathrm{RI}=$ 
$0.717, \mathrm{RC}=0.503)$. The strict consensus and bootstrap values greater than $50 \%$ are shown in Fig. 8. Analysis of the partial COI gene showed a 0-2.19\% sequence divergence within the E. schiaparelli specimens (Table 2, Fig. 8) and that these specimens form a distinct clade within Epimeria. This divergence within E. schiaparelli is much less than this group's divergence from E. macrodonta (8.93-8.38\%), the most closely related species. Divergences between other species were much larger (e.g., 12.02\% divergence for E. similis and E. macrodonta (Table 2, Fig. 8)) further supporting the conspecificity of all specimens identified as E. schiaparelli, despite conspicuous variation in some morphological characters.

TABLE 2. Uncorrected genetic COI distances (549 bases analysed).

\begin{tabular}{|c|c|c|c|c|c|c|c|c|c|c|c|c|c|c|}
\hline & $\begin{array}{l}\text { Accession } \\
\text { number }\end{array}$ & E. reoproi & $\mathrm{A}$ & B & $\mathrm{C}$ & $\mathrm{D}$ & $\mathrm{E}$ & $\mathrm{F}$ & $\mathrm{G}$ & $\mathrm{H}$ & I & $\mathrm{J}$ & $\mathrm{K}$ & $\mathrm{L}$ \\
\hline $\mathrm{A}-E$. macrodonta & AF451343 & 10.75 & & & & & & & & & & & & \\
\hline $\mathrm{B}-$ E. similis & AF451346 & 11.66 & 12.02 & & & & & & & & & & & \\
\hline $\begin{array}{l}C-E . \text { schiaparelli } \\
\text { (NIWA18181) }\end{array}$ & AM176763 & 11.11 & 8.93 & 12.93 & & & & & & & & & & \\
\hline $\begin{array}{l}D-E . \text { schiaparelli } \\
\text { (NIWA18184) }\end{array}$ & AM176764 & 11.48 & 8.56 & 13.12 & 1.64 & & & & & & & & & \\
\hline $\begin{array}{l}E-E . \text { schiaparelli } \\
\text { (NIWA18180) }\end{array}$ & AM398942 & 11.11 & 8.38 & 12.57 & 0.55 & 1.09 & & & & & & & & \\
\hline $\begin{array}{l}F-E . \text { schiaparelli } \\
\text { (NIWA18178) }\end{array}$ & AM176765 & 11.29 & 8.74 & 13.66 & 2.19 & 1.64 & 1.64 & & & & & & & \\
\hline $\begin{array}{l}G-E \text {. schiaparelli } \\
\text { (NIWA18179) }\end{array}$ & AM176767 & 11.48 & 8.56 & 13.12 & 1.28 & 1.09 & 0.73 & 1.64 & & & & & & \\
\hline $\begin{array}{l}H-E . \text { schiaparelli } \\
\text { (NIWA18185) }\end{array}$ & AM176768 & 11.32 & 8.40 & 12.78 & 0.73 & 0.91 & 0.18 & 1.46 & 0.55 & & & & & \\
\hline $\begin{array}{l}\text { I-E. schiaparelli } \\
\text { (NIWA18183) }\end{array}$ & AM176769 & 11.14 & 8.40 & 12.60 & 0.55 & 1.09 & 0.00 & 1.64 & 0.73 & 0.18 & & & & \\
\hline $\begin{array}{l}J-E . \text { schiaparelli } \\
\text { (NIWA18198) }\end{array}$ & AM176770 & 11.32 & 8.40 & 12.96 & 1.46 & 0.18 & 0.91 & 1.46 & 0.91 & 0.73 & 0.91 & & & \\
\hline $\begin{array}{l}K-E . \text { schiaparelli } \\
\text { (NIWA18195) }\end{array}$ & AM176771 & 11.32 & 8.76 & 13.69 & 2.19 & 1.82 & 1.64 & 0.18 & 1.82 & 1.64 & 1.64 & 1.64 & & \\
\hline $\begin{array}{l}\text { L-E. schiaparelli } \\
\text { (NIWA18199) }\end{array}$ & AM176772 & 11.34 & 8.59 & 12.81 & 0.73 & 1.28 & 0.18 & 1.83 & 0.92 & 0.37 & 0.18 & 1.10 & 1.83 & \\
\hline $\begin{array}{l}M-E . \text { schiaparelli } \\
\text { (NIWA18194) }\end{array}$ & AM176773 & 11.14 & 8.40 & 12.60 & 0.55 & 1.09 & 0.00 & 1.64 & 0.73 & 0.18 & 0.00 & 0.91 & 1.64 & 0.18 \\
\hline
\end{tabular}

\section{Discussion}

Validity of Epimeria similis and E. macrodonta

The identities of Epimeria macrodonta and E. similis have long been confused. This confusion started with Walker's (1906) very short original description of E. macrodonta. Walker's (1907) later, more detailed description and illustrations of this species referred to four specimens from two collections from the Antarctic Peninsula that constitute the syntype series. Examination of the syntypes, now held at the Natural History Museum, London, revealed one dissected specimen with most mouthparts and coxae missing. Further, the largest of the four specimens (Natural History Museum, London, labelled "No 13") differs appreciably from 
the Walker's (1907) description of E. macrodonta. In particular, it lacks lateral teeth on pereonite 1, pereonite 1 is $1.5 \mathrm{x}$ pereonite 2 in length (pereonite $2: 1$ is $1.2 \mathrm{x}$ pereonite 1 in the illustrated specimen) and the carinae on pereonites 3-7 and urosomites 1-2 are broader and shorter than those of the illustrated specimen. The largest specimen is not the same species as illustrated by Walker, and the type series is a composite. We draw the conclusion that the type series comprises more than one species and therefore a lectotype designation is necessary to fix the identity of the species. The paralectotypes, including the 'large' specimen, are identified as Epimeria cf. similis, for which further genetic characterisation will hopefully give final clarification. Therefore, another specimen (Natural History Museum, London, labelled "J107") which closely resembles that described and illustrated by Walker (1907) is here designated the lectotype of E. macrodonta.

In erecting E. similis, Chevreux (1912) noted that it differed from E. macrodonta Walker, 1906 in several characters, including the presence of a dorsal carina on pereonite 2 . The validity of this separation was supported by Schellenberg (1926) who added that E. similis possessed dorsolateral teeth on all pereonites. Subsequently, Barnard (1930) synonymised the two species, regarding many of Walker's (1907) and Chevreux's (1912) reported differences between the two as morphological variation. Despite making the synonymy, Barnard (1932) continued to identify two forms within Discovery expedition material: E. macrodonta forma macrodonta (one juvenile specimen from the Palmer Archipelago) and E. macrodonta forma similis (80 specimens from South Shetlands and the Palmer Archipelago).

Watling \& Holman (1981) accepted Barnard's (1930) synonymy, identifying their northern Antarctic Peninsula material as E. macrodonta forma similis, and regarding as aberrant the one specimen (of 14) that bore a midventral tooth distally on antenna 1 peduncle article 2 , and lacked a carina on pereonite 1 .

Andres (1985) checked Barnard's (1932) Discovery material and subsequently regarded E. similis as a valid species. According to Andres (1985), E. similis is the only species of Epimeria with lateral teeth on all pereonites and pleonites, and lacking a dorsal carina on pereonite 2, whereas pereonites 1-2 are smooth in $E$. macrodonta. Andres (1985) may have not checked the type material of E. macrodonta, because the largest syntype does bear lateral teeth on pereonites 1-2 (contrasting with Walker's (1907) description and illustrations of E. macrodonta). The present investigation confirms the validity of E. similis based on type material in the Muséum national Histoire naturelle, Paris, genetic evidence, and from a better understanding of the intraspecific morphological variation within the closely related E. schiaparelli.

\section{Distribution of Epimeria macrodonta complex species}

The distributions of the three species comprising the Epimeria macrodonta complex can now be clarified. Epimeria macrodonta appears to be limited to the Weddell Sea and the Antarctic Peninsula at 0-900 m depth, and has not been found in the Ross Sea (Andres 1985; present study). Epimeria similis is distributed throughout the eastern Antarctic and the Scotia area, inhabiting 165-420 m depth (Andres 1985). In comparison, $E$. schiaparelli has been found only in the Ross Sea, at 130-350 m depth.

\section{Variation and radiation of Epimeria $c f$. similis}

In addition to E. schiaparelli, the BioRoss Expedition 2004 collected more than 40 specimens of an Epimeria species that closely resembles E. similis. These specimens closely resemble E. similis morphologically, but had only a single acute process on coxa 4 . These specimens also differed from E. similis in that the distal spines on antenna 1 peduncle articles 1-2 were shorter, pereonite 2 was longer and the acute lateral process on coxa 5 was shorter than in E. similis. Since subtle morphological distinctions have proven to be reliable in the distinction of Epimeria species, we have good evidence that we have another new species within the Epimeria similis complex. It is presently under study and the further genetic studies will reveal its phylogenetic position. 


\section{Molecular data}

In a morphological analysis of Antarctic Epimeria, Lörz \& Brandt (2004) noted that some species, such as E. similis and E. robusta, are highly variable morphologically. They suggested that recent speciation of the Epimeriidae had occurred in the Southern Ocean. Molecular data on the phylogeny of Antarctic Epimeria species (Lörz \& Held 2004) supports the theory of recent speciation when Antarctica cooled, and after the Drake Passage formed.

The molecular data presented here clearly supports E. schiaparelli as a new species, with the nearest congeners, E. macrodonta, E. reoproi and E. similis, all showing greater than $8 \%$ sequence divergence. This level of sequence divergence is similar to that previously documented between species of Epimeria (see Lörz \& Held 2004). In addition, Väinölä et al. (2001) observed 4.8-12.5\% COI gene sequence divergences between species of the amphipod genus Gammaracanthus Bate, 1862. These interspecific data are consistent with our findings, which show a minimum interspecific divergence of $8.38 \%$ between Epimeria species. The intraspecific variation within the 11 specimens of $E$. schiaparelli sequenced was 0-2.19\% sequence divergence, corroborating the validity of $E$. schiaparelli despite the small morphological differences observed.

\section{Colouration}

Two colour patterns were recorded from freshly captured specimens of E. schiaparelli (Figs 7A, B). The most common form was a pattern of irregular orange patches (Fig. 7A), but five specimens (NIWA 1817718180) had distinctive red-orange bands when alive (Fig. 7B). Large and small specimens of both males and females had each colour pattern, so colouration was not size or sex related. The colour pattern was also independent of locality or depth of occurrence. Further, molecular data using the COI revealed that the different colour morphotypes do not form a separate clade and that the sequence differences between the two coloured forms (NIWA18180, NIWA18178 and NIWA18181) and the other morphotype (all other sequences) is the same as the interspecific divergence $(0-2.19 \%)$. The sequence divergences within the colour morphotypes is $0.55-2.19 \%$ and the divergence within the non coloured morphotype is $0.0-1.83$.

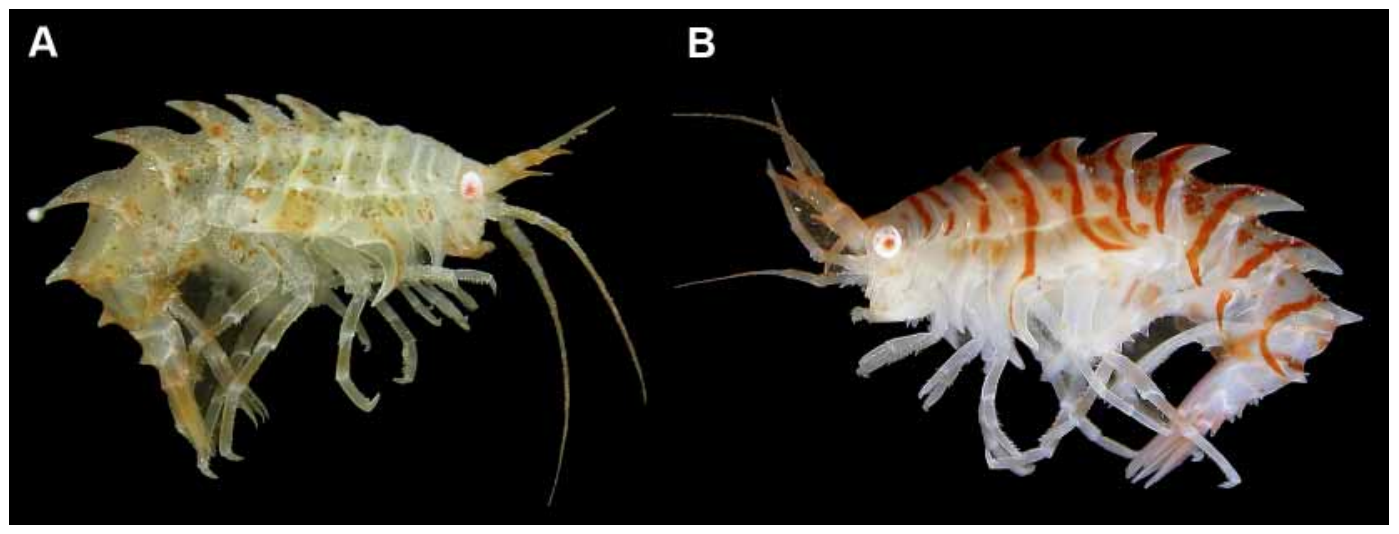

FIGURE 7. Epimeria schiaparelli sp. nov. Colour patterns. A, irregular orange patches, paratype, NIWA 18182; B, striped form, ovigerous female paratype, NIWA 18176.

\section{Acknowledgements}

The material examined during the current study was obtained during a biodiversity survey of the northwestern Ross Sea and Balleny Islands undertaken by the National Institute of Water and Atmospheric Research and financed by the Ministry of Fisheries (Project ZBD200303). Thanks are due to the captain, officers, crew and scientific personnel of RV Tangaroa. We are especially grateful for Dr. Stefano Schiaparelli for photographing specimens in their live colours while on board ship. We are grateful to Miranda Lowe, The Natural History 
Museum, London, and Dr. Danielle Defaye, Muséum National Histoire Naturelle, Paris, for the loan of Epimeria type material. We thank Dr. Niel Bruce (NIWA) for his critical comments on an earlier version of the paper and for heaps and heaps of clever, sophisticated, and repeated editorial assistance; and Kareen Schnabel (NIWA) for electronically inking four plates. We are also grateful for the friendly assistance in the genetic lab from Cara Brosnahan (NIWA) and Therese Cope (BAS). The authors Lörz and Fenwick received Fisheries Science Fund (FSF2004) for the taxonomic component of this research. The authors Lörz and Linse gratefully received an International Science and Technology (ISAT) Linkage fund to conduct the molecular work. The taxonomy work was partially funded through the Foundation for Research Science and Technology programme CO01X0502.

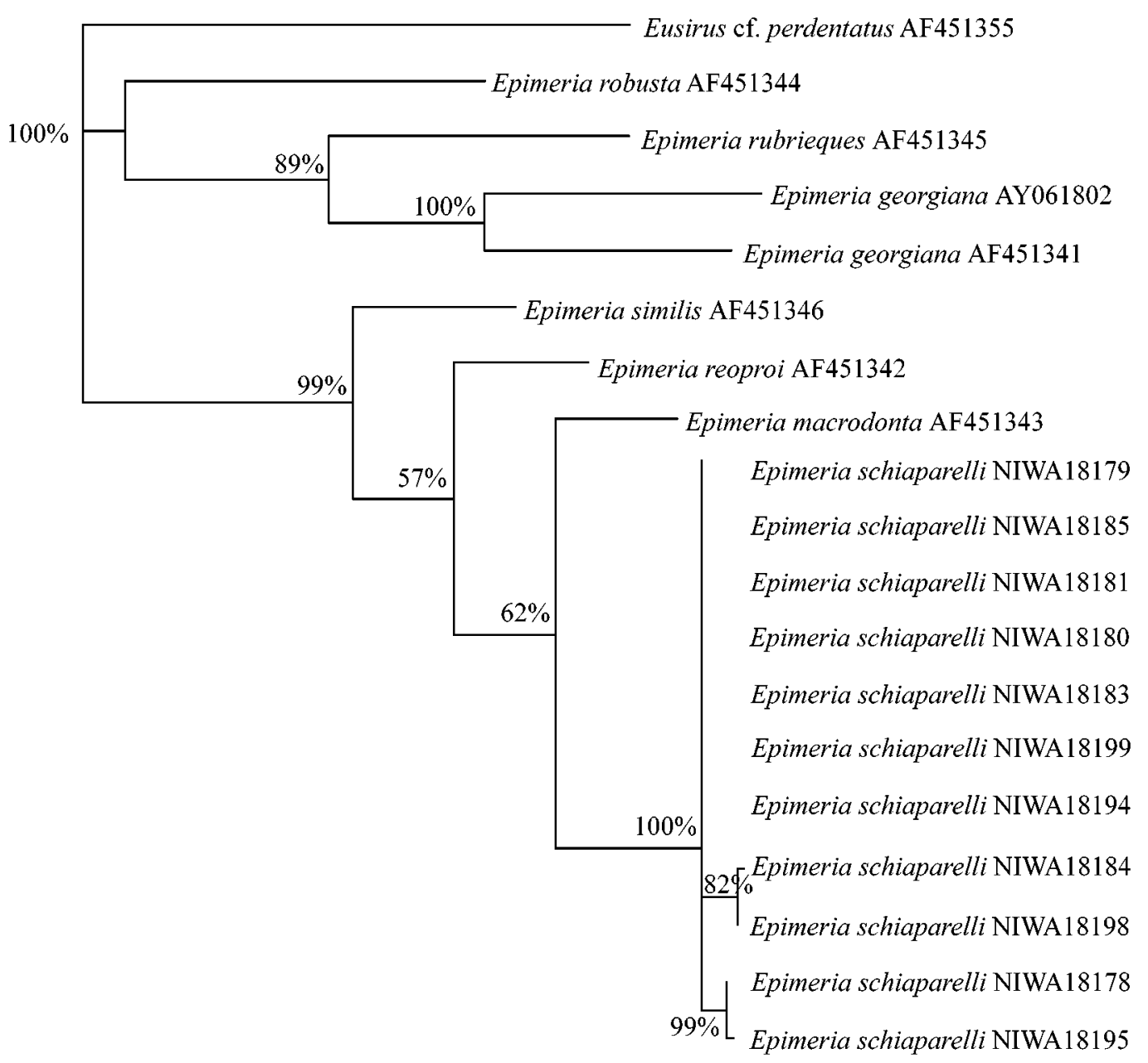

FIGURE 8. Strict consensus tree ( $\mathrm{n}=12$ trees) of a maximum parsimony analysis based on 549 nucleotides from the COI gene $(\mathrm{TL}=457, \mathrm{CI}=0.702, \mathrm{HI}=30298, \mathrm{RI}=0.717, \mathrm{RC}=0.503)$. Numbers at branches indicate bootstrap support (1000 replicates) of over $50 \%$.

\section{References}

Andres, H. (1985) Die Gammaridea (Crustacea: Amphipoda) der Deutschen Antarktis-Expeditionen 1975/76 und 1977/ 78. 4. Acanthonotozomatidae, Paramphithoidae und Stegocephalidae. Mitteilungen aus dem Hamburgischen Zoologischen Museum und Institut, 82, 119-153.

Barnard, K. (1930) Amphipoda. British Antarctic ("Terra Nova") Expedition, 1910. Natural History Report, Zoology, $8(4), 307-454$.

Barnard, K. (1932) Amphipoda. Discovery Reports, V, 1-326. 
Barnard, J.L. \& Karaman, G.S. (1991) The families and genera of marine gammaridean Amphipoda (except marine Gammaroidea). Records of the Australian Museum, Supplement 13, Part 1, 1-417, Part 2, 418-866.

Chevreux, E. (1912) Amphipodes. Deuxième Expédition Antarctique Francaise (1908-1910) commandée par le Dr Jean Charcot. Sciences Naturelles: Documents Scientifiques, 79, 10-186.

Coleman, C.O. \& Barnard, J.L. (1991) Revision of Iphimediidae and similar families (Amphipoda: Gammaridea). Proceedings of the Biological Society of Washington, 104, 253-268.

Folmer, O., Black, M., Hoeh, W., Lutz, R. \& Vrijenhoek, R. (1994) DNA primers for amplification of mitochondrial cytochrome c oxidase subunit I from diverse metazoan invertebrates. Molecular Marine Biology and Biotechnology, 3, 294-299.

Lörz, A.N. (2003) Studies on the biodiversity of Antarctic benthic Amphipoda (Malacostraca, Crustacea). Berichte zur Polar-und Meeresforschung - Reports on Polar and Marine Research, 452, 1-148.

Lörz, A.N. \& Brandt, A. (2004) Phylogeny of Antarctic Epimeria (Epimeriidae: Amphipoda). Journal of the Marine Biological Association of the United Kingdom, 84(1), 179-190.

Lörz, A.N. \& Held, C. (2004) A preliminary molecular and morphological phylogeny of the Antarctic Epimeriidae and Iphimediidae (Crustacea, Amphipoda). Molecular Phylogenetics and Evolution, 31(1), 4-15.

Ludwig, W., Strunk, O., Westram, R., Richter, L., Meier, H., Yadhukumar, Buchner, A., Lai, T., Steppi, S., Jobb, G., Forster, W., Brettske, I., Gerber, S., Ginhart, A.W., Gross, O., Grumann, S., Hermann, S., Jost, R., Konig, A., Liss, T., Lussmann, R., May, M., Nonhoff, B., Reichel, B., Strehlow, R., Stamatakis, A., Stuckmann, N., Vilbig, A., Lenke, M., Ludwig, T., Bode, A. \& Schleifer, K.H. (2004) ARB: a software environment for sequence data. Nucleic Acids Research, 32, 1363-1371.

Schellenberg, A. (1926) Die Gammariden der deutschen Südpolarexpedition 1901-1903. Deutsche Südpolarexpedition, $18,235-414$.

Swofford, D.L. (2002) PAUP* Phylogenetic Analysis Using Parsimony (*and Other Methods). Version 4. Sunderland, MA: Sinauer Associates.

Väinölä, R., Vainio, J.K. \& Palo, J.U. (2001) Phylogeography of "glacial relict" Gammaracanthus (Crustacea, Amphipoda) from boreal lakes and the Caspian and White seas. Canadian Journal of Fisheries and Aquatic Sciences, 58, 2247-2257.

Walker, A. (1906) Preliminary descriptions of new species of Amphipoda from the Discovery Antarctic Expedition, 1902-1904. Annals and Magazine of Natural History, Series 7, 17, 452-458.

Walker, A.O. (1907) Crustacea. III. Amphipoda. National Antarctic Expedition 1901-1904. Natural History, 3, 1-39.

Watling, L. \& Holman, H. (1981) Additional acanthonotozomatid, paramphithoid, and stegocephalid Amphipoda from the Southern Ocean. Proceedings of the Biological Society of Washington, 94(1), 181-227.

Watling, L. (1989) Classification system for crustacean setae based on the homology concept. In: Felgenhauer, B.E., Watling, L. \& Thistle, A.B (Eds.) Functional morphology of feeding and grooming in Crustacea. A.A. Balkema, Rotterdam, pp. 214 